\title{
Comparison of the effects of the n-3 polyunsaturated fatty acid eicosapentaenoic and fenofibrate on the inhibitory effect of arthritis on IGF1
}

\author{
Estíbaliz Castillero, María López-Menduiña, Ana Isabel Martín, María Ángeles Villanúa \\ and Asunción López-Calderón
}

Department of Physiology, Faculty of Medicine, Complutense University of Madrid, 28040 Madrid, Spain

(Correspondence should be addressed to A López-Calderón; Email: alc@med.ucm.es)

\begin{abstract}
Adjuvant-induced arthritis is a chronic inflammatory illness that induces muscle wasting and decreases circulating IGF1. Eicosapentaenoic acid (EPA) and fenofibrate, a peroxisome proliferator-activated receptors $\alpha$ agonist, have anti-inflammatory actions and ameliorate muscle wasting in arthritic rats. The aim of this work was to elucidate whether EPA and fenofibrate administration are able to prevent the effect of arthritis on the IGF1-IGFBP system. On day 4 after adjuvant injection control, arthritic rats were gavaged with EPA $(1 \mathrm{~g} / \mathrm{kg})$ or fenofibrate $(300 \mathrm{mg} / \mathrm{kg})$ until day 15 when all rats were killed. Arthritis decreased body weight gain, serum IGF1, and liver Igf1 mRNA, whereas it increased gastrocnemius Igfbp 3 mRNA. EPA, but not fenofibrate,
\end{abstract}

administration prevented arthritis-induced decrease in serum IGF1 and liver Iof1 mRNA. In the rats treated with EPA arthritis increased Igfbp 5 mRNA in the gastrocnemius. Fenofibrate treatment decreased IGF1 and Igf1 mRNA in the liver and gastrocnemius. In arthritic rats, fenofibrate increased body weight gain and decreased gastrocnemius Igfbp 3 and Igfbp 5 mRNA. These data suggest that the mechanisms through which EPA and fenofibrate act on the IGF1 system and ameliorate muscle wasting in arthritic rats are different. EPA administration increased circulating levels of IGF1, whereas fenofibrate decreased the Igfbp 3 and Igfbp 5 in the gastrocnemius muscle.

Journal of Endocrinology (2011) 210, 361-368

\section{Introduction}

Chronic inflammation is often associated with skeletal muscle wasting and cachexia (Evans et al. 2008). Inflammatory cachexia has been reported in chronic illnesses such as cancer, heart or renal failure, Crohn's disease, sepsis, and rheumatoid arthritis. Cachexia can also induce a decrease in body weight that is associated with muscle atrophy and sometimes with fat mass depletion. The increased release of cytokines and other proinflammatory mediators plays a crucial role in inflammatory cachexia (Morley et al. 2006). However, inflammation induces deep modifications in the neuroendocrine system that might also contribute to a decrease in body weight, muscle wasting, and cachexia (Morley et al. 2006). These modifications include an increase in the release of glucocorticoids with a decrease in anabolic hormones such as androgens and insulin-like growth factor 1 (IGF1; Soto et al. 1998).

Adjuvant-induced arthritis is an experimental model of rheumatoid arthritis that is associated with a decrease in body weight and muscle wasting (Castillero et al. 2009a). Arthritic rats have low serum IGF1 levels that are inversely related to body weight gain (López-Calderón et al. 1999), whereas chronic GH administration to arthritic rats increases body weight and serum IGF1 levels (Ibañez de Cáceres et al. 2000). Similarly, GH administration to juvenile RA patients increases growth (Touati et al. 1998). Furthermore, exogenous IGF1 administration to arthritic rats increases body and skeletal muscle weights (López-Menduiña et al. 2010). All these data indicate that arthritis-induced decrease in circulating IGF1 is an important contributor to the decrease in body weight and skeletal muscle wasting induced by experimental arthritis.

Eicosapentaenoic acid (EPA) is an n-3 polyunsaturated fatty acid that is essential for normal growth and is present in large amounts in fish oil. It is well known that EPA has an anti-inflammatory effect decreasing proinflammatory cytokines (Tashiro et al. 1998, Zhao et al. 2004) and both cyclooxygenase-2 activity and expression (Hurst et al. 2009). Furthermore, EPA is able to decrease joint inflammation in rheumatoid arthritis patients (James \& Cleland 1997, Simopoulos 2002) and in arthritic rats (Leslie et al. 1985, Volker et al. 2000, Castillero et al. 2009b). In addition to its anti-inflammatory effect, EPA ameliorates arthritis-induced skeletal muscle wasting by decreasing atrogin-1 and Murf-1 gene expression and also increasing the transcription factors 
that regulate myogenesis (Castillero et al. 2009a). Taking into account that the beneficial effect of IGF1 treatment on skeletal muscle in arthritic rats is also associated with decreased atrogin-1 and increased myogenic regulatory factors (López-Menduiña et al. 2010), it is possible that EPA administration can prevent arthritis-induced inhibition of IGF1.

EPA has several mechanisms of action, and one of these is through the activation of peroxisome proliferator-activated receptors (PPARs; Forman et al. 1997). PPARs are nuclear transcription factors that regulate genes involved in the control of metabolism and inflammatory responses (Michalik \& Wahli 2008). In hepatocytes, EPA has been reported to activate PPAR $\alpha$ (Pawer \& Jump 2003) and upregulate Ppar $\alpha$ gene expression (Liu et al. 2011). Fenofibrate, a PPAR $\alpha$ ligand, inhibits cytokine production from rheumatoid synovial fibroblasts and inhibits the development of adjuvant-induced arthritis in female Lewis rats (Okamoto et al. 2005). In arthritic rats, we have reported that fenofibrate administration increases body weight and decreases skeletal muscle atrophy through inhibition of atrogin-1, Murf-1, and myostatin expression in skeletal muscle (Castillero et al. 2011). These data indicate that EPA and fenofibrate have comparable effects on skeletal muscle in arthritic rats. To clarify whether the effect of EPA can be mediated by PPAR $\alpha$ activation, we have compared the response of the IGF-IGFBPs system to experimental arthritis in rats fed with either EPA or the $\operatorname{PPAR} \alpha$ activator fenofibrate.

\section{Materials and Methods}

\section{Animals}

Arthritic and control male Wistar rats weighing $150 \mathrm{~g}$ were purchased from Charles River (Barcelona, Spain). Arthritis was induced in the rats by a s.c. injection of $4 \mathrm{mg}$ heatinactivated Mycobacterium butyricum in the right hind paw, under isoflurane anesthesia (Castillero et al. 2009a). Control animals were injected with vehicle $(0 \cdot 1 \mathrm{ml}$ paraffin oil). After arrival (day 3 after adjuvant injection), rats were housed 3 per cage, and maintained under standardized conditions of temperature $\left(20-22^{\circ} \mathrm{C}\right.$ ) and light (lights on from 0730 to $1930 \mathrm{~h}$ ). Assessment of arthritis was performed by measuring the arthritis index of each animal, which was clinically scored by grading each paw from 0 to 4 . Grading was determined as: 0 , no erythema or swelling; 1 , slight erythema or swelling of one or more digits; 2 , swelling of paw; 3 , swelling of entire paw and ankle; and 4, ankylosis, incapacity to bend the ankle. The severity score was the sum of the clinical scores of each limb, the maximum value being 16 (Tanaka et al. 1996). The procedures followed the guidelines recommended by the EU for the care and use of laboratory animals, and were approved by the Complutense University animal care committee.

\section{Treatments}

EPA 18 control and 18 arthritic rats were divided into two groups on day 4 after adjuvant injection. The first group received a daily dose of $1 \mathrm{~g} / \mathrm{kg} \mathrm{BW}$ highly purified ethyl ester of EPA (E-EPA) containing 90\% EPA and 0.02\% vitamin $\mathrm{D}_{3}$ (Oy Bio-Vita Ab, Espoo, Finland) by oral gavage. The other group received $1 \mathrm{~g} / \mathrm{kg} \mathrm{BW}$ of coconut oil to ensure isocaloric intake. Coconut oil has a high concentration of short- $(8-10$ carbons) and medium-chain saturated fatty acids (12-16 carbons). Since arthritis decreases food intake, a pair-fed group of nine rats treated with coconut oil was also included. Pair-fed rats received the same amount of food (g/100 g BW) eaten on the previous day by arthritic rats treated with coconut oil.

Fenofibrate On day 4 after adjuvant injection, 18 control and 18 arthritic rats were each divided into two groups. The first group received fenofibrate $(300 \mathrm{mg} / \mathrm{kg} \mathrm{BW}$, suspended in $500 \mu 1 \%$ carboxymethylcellulose (CMC), Sigma-Aldrich) daily by oral gavage. The second group was gavaged with vehicle $(500 \mu \mathrm{l} 1 \% \mathrm{CMC})$. A pair-fed group of nine rats treated with vehicle was also included.

All rats were killed on day 15 after adjuvant injection and after 12 days of treatment. Trunk blood was collected in cooled tubes, allowed to clot, centrifuged and the serum was stored at $-20^{\circ} \mathrm{C}$ until IGF1 and IGFBP3 assays were performed. Immediately after decapitation, left gastrocnemius and liver were dissected, frozen in liquid nitrogen and stored at $-80{ }^{\circ} \mathrm{C}$ until RNA extraction. Isolation and manipulation of tissues were always performed under sterile conditions.

\section{$R N A$ extraction and real-time $P C R$}

Gastrocnemius or liver (100 mg) was homogenized, and total RNA was extracted using Ultraspec (Biotecx Laboratories, Inc., Houston, TX, USA), following the manufacturer's protocol. The final concentration of RNA was determined (260 nm) with a BioPhotometer (Eppendorf, Germany), and the integrity of the RNA was confirmed by agarose gel electrophoresis. First-strand cDNA synthesis was performed by $1 \mu \mathrm{g}$ of total RNA with a Quantiscript Reverse Transcription kit (Qiagen).

Real-time PCR for quantification of mRNA was performed on a SmartCycler (Cepheid, Sunnyvale, CA, USA) using a SYBR Green protocol on the fluorescence temperature cycler. Each real-time PCR consisted of $10 \mathrm{ng}$ total RNA equivalents, $1 \times$ Takara SYBR Green Premix Ex Taq (Takara BIO, Inc., Otsu, Shiga, Japan), and $300 \mathrm{nM}$ forward and reverse primers in a reaction volume of $25.5 \mu \mathrm{l}$. Primers for real-time PCR (Table 1), were obtained from Roche. The thermal cycling profile consisted of a preincubation step at $95^{\circ} \mathrm{C}$ for $10 \mathrm{~s}$ followed by 40 cycles of $95{ }^{\circ} \mathrm{C}$ denaturation steps for $15 \mathrm{~s}, 60{ }^{\circ} \mathrm{C}$ annealing steps for $30 \mathrm{~s}$, and $72{ }^{\circ} \mathrm{C}$ extension steps for $30 \mathrm{~s}$. Results were 
Table 1 Primers for real-time PCR

Primers $\left(5^{\prime}-3^{\prime}\right)$

\begin{tabular}{|c|c|c|c|}
\hline & & Primers $\left(5^{\prime}-3^{\prime}\right)$ & Product $(b p)$ \\
\hline \multicolumn{4}{|l|}{ Gene } \\
\hline \multirow[t]{2}{*}{$18 S$} & $\mathrm{~F}:$ & GGTGCATGGCCGTTCTTA & 60 \\
\hline & R: & TCGTTCGTTATCGGAATTAACC & \\
\hline \multirow[t]{2}{*}{ lgf1 } & $\mathrm{F}:$ & GCTATGGCTCCAGCATTCG & 62 \\
\hline & R: & TCCGGAAGCAACACTCATCC & \\
\hline \multirow[t]{2}{*}{ lgfbp3 } & $\mathrm{F}:$ & GGAAAGACGACGTGCATTG & 78 \\
\hline & R: & GCGTATTTGAGCTCCACGTT & \\
\hline \multirow[t]{2}{*}{ Igfbp5 } & $\mathrm{F}:$ & GGCGAGCAAACCAAGATAGA & 75 \\
\hline & R: & GGTCTCСTCAGССАTCTCG & \\
\hline
\end{tabular}

F, forward; R, reverse.

expressed relative to the control animals treated with coconut oil or vehicle, where the relative mRNA abundance has been arbitrarily set to 1 , using cycle threshold $2\left(\Delta \Delta C_{\mathrm{T}}\right)$ method, with $18 \mathrm{~S}$ as reference gene. PCR products were separated using agarose gel electrophoresis to confirm the product presence and size.

\section{IGF1 and corticosterone determinations}

Serum IGF1 was measured using the antiserum to human IGF1 (UB2-495) from Dr Underwood and Dr Van Wik, and is distributed by the NIDDK Hormone Distribution Program through the National Hormone and Pituitary Program. Levels of IGF1 were expressed in terms of rat IGF1 from Gropep Ltd (Adelaide, SA, Australia). The intra-assay coefficient of variation was $8 \%$. All samples from the same experiment were run in the same assay. Serum corticosterone was analyzed by a commercial kit from MP Biomedicals, LLC (New York, NY, USA).

\section{Ligand blot}

Serum concentrations of IGFBP3 were measured by western blot. Serum $(2 \mu \mathrm{l})$ was diluted in sample buffer and boiled for $2 \mathrm{~min}$ at $90^{\circ} \mathrm{C}$, loaded onto $1 \%$ SDS- $12 \cdot 5 \%$ polyacrylamide gels, and electrophoresed under nonreducing conditions. Proteins were transferred onto nitrocellulose sheets (Hybond-C extra, Amersham, UK). The membranes were dried and blocked for $1 \mathrm{~h}$ with 5\% non-fat dry milk, $0 \cdot 1 \%$ Tween (Sigma), in Tris-buffered saline. Membranes were probed overnight at $4{ }^{\circ} \mathrm{C}$ with ${ }^{125}$ I-labeled IGF1 $(1.5 \times 106$ c.p.m. $/ \mathrm{ml})$. The nitrocellulose sheets were then washed, dried, and exposed at $-80{ }^{\circ} \mathrm{C}$ to $\mathrm{X}$-ray film (Kodak X-Omat AR, Eastman Kodak) and to two intensifying screens for 1-4 days according to the signal obtained. The signals of the film were quantified by densitometry using a PC Image VGA24 program for Windows. The density of the IGFBP3 band in each lane was expressed as the percentage of the mean density of sera from their respective control rats.

\section{Statistical analysis}

Statistics were computed using the statistics program STATGRAPHICS plus for Windows. Data are presented as means \pm s.E.M. and were tested with ANOVA; post hoc comparisons were made by the LSD multiple range test. Statistical significance was set at $P<0 \cdot 05$.

\section{Results}

\section{Effect of EPA administration}

Arthritis decreased body weight gain to values lower than in pair-fed rats (Table 2). EPA administration was unable to modify body weight gain in arthritic or control rats. However, EPA treatment decreased the external signs of arthritis (Table 2). Figure 1 shows the effect of arthritis and EPA administration on serum concentration of IGF1, IGFBP3, and corticosterone. In rats treated with coconut oil, arthritis decreased serum concentrations of IGF1, whereas it increased corticosterone levels. In addition, pair-fed rats had IGF1 serum concentrations similar to arthritic rats, and corticosterone concentrations slightly lower but not significantly different. EPA administration did not modify serum concentrations of these hormones in control rats, but prevented the inhibitory effect of arthritis on serum concentrations of IGF1. Arthritis did not modify serum concentrations of IGFBP3 or its gene expression in the liver (Figs $1 \mathrm{~B}$ and $2 \mathrm{~B}$ ). Igf1 mRNA in the liver was also decreased in pair-fed and in arthritic rats treated with coconut oil (Fig. 2A). EPA administration did not modify Igf1 expression in the liver of control rats, but increased Igf1 mRNA levels in the liver of arthritic rats to levels similar to control rats (Fig. 2A).

Table 2 Effect of eicosapentaenoic acid (EPA) or fenofibrate administration, from day 4 to day 15 after adjuvant injection, on body weight gain and arthritis score in control and arthritic (AA) rats. Data are mean \pm S.E.M. for $8-9$ rats

\begin{tabular}{|c|c|c|}
\hline & $\begin{array}{l}\text { Body weight } \\
\text { gain days 4-15 g }\end{array}$ & Arthritis score \\
\hline Control - coconut oil & $62 \pm 3 \cdot 4$ & \\
\hline AA-coconut oil & $18 \pm 3 \cdot 8^{\mathrm{a}}$ & $10 \cdot 2 \pm 1 \cdot 1$ \\
\hline Pair-fed & $31 \pm 1 \cdot 7^{\mathrm{a}}$ & \\
\hline Control-EPA & $62 \pm 4 \cdot 0$ & \\
\hline AA-EPA & $19 \pm 5 \cdot 6^{b, c}$ & $6 \cdot 2 \pm 4 \cdot 0^{\mathrm{d}}$ \\
\hline Control - vehicle & $67 \pm 2 \cdot 5$ & \\
\hline AA-vehicle & $19 \pm 3 \cdot 6^{a}$ & $11 \cdot 1 \pm 1 \cdot 2$ \\
\hline Pair-fed & $38 \pm 1 \cdot 5^{a}$ & \\
\hline Control-fenofibrate & $70 \pm 2 \cdot 7$ & \\
\hline AA-fenofibrate & $32 \pm 7 \cdot 0^{b, d}$ & $6 \cdot 4 \pm 1 \cdot 2^{\mathrm{d}}$ \\
\hline
\end{tabular}

Journal of Endocrinology (2011) 210, 361-368 


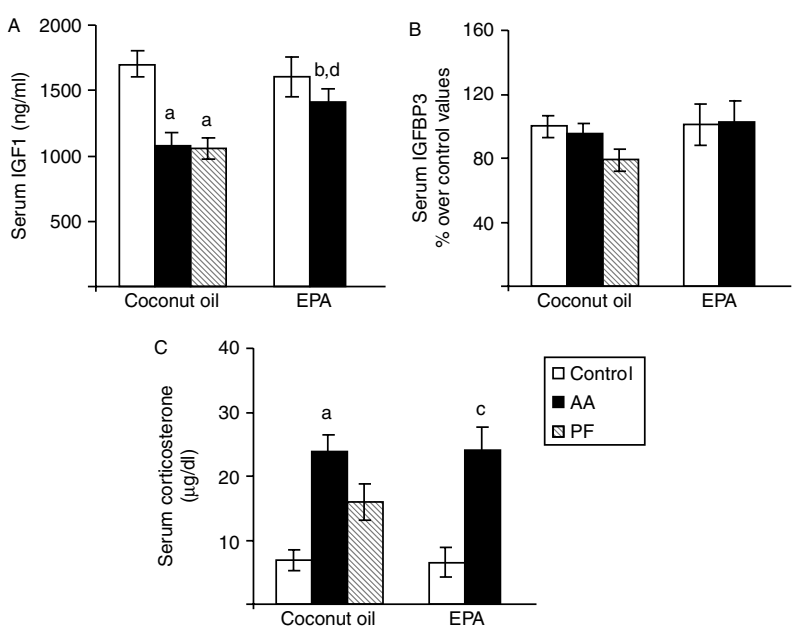

Figure 1 Serum concentrations of IGF1 (A), IGFBP3 (B), and corticosterone $(\mathrm{C})$ in control, arthritic (AA) or pair-fed (PF) rats treated with $1 \mathrm{~g} / \mathrm{kg}$ EPA or $1 \mathrm{~g} / \mathrm{kg}$ coconut oil. Arthritis decreased serum concentrations of IGF1 in rats treated with coconut oil $(P<0 \cdot 01)$ but not in those that received EPA. Corticosterone levels were increased in the two groups of arthritic rats, treated with coconut oil or EPA $(P<0 \cdot 05)$. Pair-fed rats had similar serum concentrations of IGF1 and corticosterone than arthritic rats treated with coconut oil. Data are expressed as mean \pm S.E.M. for $n=8-9$ rats per group, a different from control rats treated with coconut oil, bdifferent from arthritic rats treated with coconut oil, ' $d i f f e r e n t$ from control rats treated with EPA, and different from pair-fed rats.

Neither arthritis nor EPA administration significantly modified Igf1 expression in the gastrocnemius, although arthritis tended to increase it (Fig. 3A). However, arthritis induced a significant increase in Igfbp 3 gene expression in the gastrocnemius muscle in rats treated with coconut oil or EPA (Fig. 3B). Arthritis also tended to increase Igbp5 in the gastrocnemius of rats treated with coconut oil, but this increase was not significant. EPA administration potentiated this effect, since the arthritic rats treated with EPA had higher Igfbp 5 mRNA levels than control rats (Fig. 3C).

\section{Effect of fenofibrate administration}

In arthritic rats treated with fenofibrate body weight gain was higher and arthritis scores were lower than in arthritic rats treated with vehicle (Table 2). In control rats body weight gain was similar in the rats treated with either fenofibrate or vehicle. Fenofibrate administration to control rats decreased serum concentrations of IGF1 to similar levels found in arthritic or pair-fed rats (Fig. 4A). As expected, arthritis increased serum concentrations of corticosterone in the rats treated with vehicle. In addition, serum corticosterone levels in the control rats treated with fenofibrate were similar to those of the arthritic or pair-fed rats (Fig. 4C). Liver Igf1 mRNA showed responses that were similar to serum concentration of IGF1, since it was decreased by arthritis and fenofibrate treatment (Fig. 5A). Neither arthritis nor fenofibrate administration modified serum concentration of IGFBP3 or its gene expression in the liver (Figs 4B and 5B).

The effect of fenofibrate treatment on the IGF system is shown in Fig. 6. Arthritis or pair-feeding the rats did not modify Igf1 mRNA in the gastrocnemius. Fenofibrate treatment decreased Igf1 mRNA levels in the gastrocnemius, but this decrease was only statistically significant in the arthritic rats treated with fenofibrate (Fig. 6A). Arthritis increased both $\operatorname{Igfbp} 3$ and $\operatorname{Igfbp} 5 \mathrm{mRNA}$ in the gastrocnemius (Fig. 6B and C). Fenofibrate treatment prevented the stimulatory effect of arthritis on Igfbp 3 and Igfbp 5 expression in the gastrocnemius.

\section{Discussion}

Our data suggest that EPA administration can prevent the inhibitory effect of chronic inflammation on serum IGF1 and liver Igf1. In contrast, treatment with the $\operatorname{PPAR} \alpha$ agonist, fenofibrate, did not only ameliorate arthritis-induced inhibition of IGF1, but it also decreased serum IGF1 as well as Igf1 expression in control rats.

The decrease in liver Igf1 mRNA and serum IGF1 in pairfed rats on day 15 after adjuvant injection suggests that the inhibitory effect of arthritis on IGF1 is secondary to the decrease in food intake. However, on day 22 after adjuvant injection, food intake in arthritic rats is similar to that of control rats, but serum IGF1 and liver Igf1 mRNA are still lower in arthritic rats than in control or in pair-fed rats (Castillero et al. 2009a). These data indicate that on day 15, the inhibitory effect of arthritis on IGF1 is due to two factors; inflammation and the lower food intake. EPA administration prevented the inhibitory effect of arthritis on IGF1 and on its expression in the liver, without increasing body weight gain. The absence of effect of EPA on body weight gain can be due to the fact that EPA does not modify food intake in arthritic rats (Volker et al. 2000, Castillero et al. 2009b). A lack of
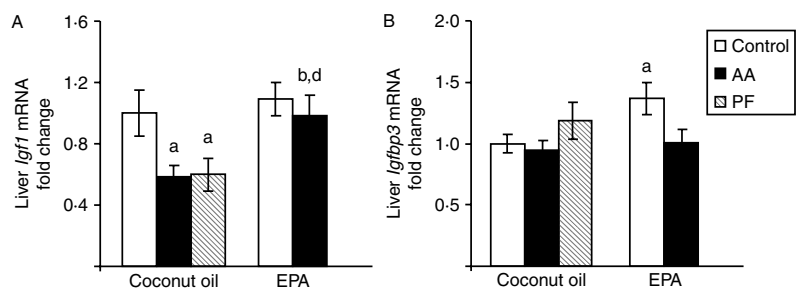

Figure 2 Effect of $1 \mathrm{~g} / \mathrm{kg}$ EPA or $1 \mathrm{~g} / \mathrm{kg}$ coconut oil administration on liver Igf1 (A) and Igfbp3 (B) mRNA in control, arthritic (AA) and pairfed $(\mathrm{PF})$ rats. Arthritis decreased Igf1 mRNA in rats treated with coconut oil $(P<0 \cdot 05)$ but not in those treated with EPA. EPA administration increased $(P<0 \cdot 05)$ lgfbp3 mRNA in control rats, but not in arthritic rats. Data are expressed as mean \pm S.E.M. for $n=8-9$ rats per group, a different from control rats treated with coconut oil, different from arthritic rats treated with coconut oil, and ${ }^{\mathrm{d}}$ different from pair-fed rats. 

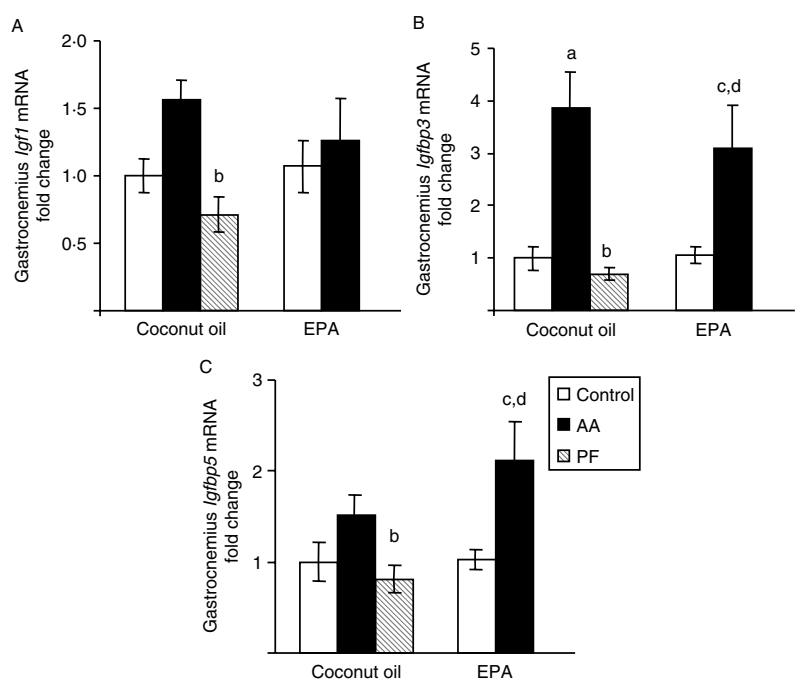

Figure 3 Effect of $1 \mathrm{~g} / \mathrm{kg}$ EPA or $1 \mathrm{~g} / \mathrm{kg}$ coconut oil administration on gastrocnemius lgf1 (A), Igfbp3 (B), and lgfbp5 (C) mRNA in control, arthritic (AA) and pair-fed (PF) rats. Arthritis increased lgfbp3 mRNA. Pair-fed rats had lower lgf1, Igfbp3, and Igfbp 5 mRNA than arthritic rats $P<0 \cdot 01$. Arthritis increased Igfbp 5 mRNA in rats treated with EPA $P<0 \cdot 01$. Data are expressed as mean \pm S.E.M. for $n=8-9$ rats per group, a different from control rats treated with coconut oil, b different from arthritic rats treated with coconut oil, ${ }^{\mathrm{c}}$ different from control rats treated with EPA, and ${ }^{\mathrm{d}}$ different from pair-fed rats.

effect of EPA on body weight together with a protective effect on muscle has also been reported in dystrophic muscle degeneration (Machado et al. 2011). All these data suggest that the protective effect of EPA on IGF1 is not related to modifications in food intake. Furthermore, fenofibrate, which increased food intake in arthritic rats (Castillero et al. 2011) and body weight gain, was unable to prevent the inhibitory effect of arthritis on serum IGF1 and liver Igf1 mRNA.

The stimulatory effect of EPA on liver Igf1 in arthritic rats can be secondary to its anti-inflammatory effect. EPA administration decreases the external signs of arthritis and prevents arthritis-induced increase in liver TNF $\alpha$ (Castillero et al. 2009a). However, fenofibrate treatment has antiinflammatory effects in arthritic rats similar to those of EPA (Castillero et al. 2011), but in the present data it was unable to restore serum IGF1 and liver Igf1 mRNA. Differences can be due to the different effect of the compounds, EPA and fenofibrate, on Igf1 expression, since fenofibrate decreased liver Igf1 expression in control rats and muscle Igf1 expression in arthritic rats.

An increase in serum concentrations of IGF1 has been reported after chronic EPA administration (Childs et al. 2008, Bonnet \& Ferrari 2010). However, in our data EPA did not modify Igf1 expression in the liver or serum IGF1 in control rats. These differences can be due to the fact that the stimulatory effect of EPA on serum concentrations of IGF1 has been reported after treatments longer than that in this study, 14 months in mice (Bonnet \& Ferrari 2010) and 45 days in cattle (Childs et al. 2008). Therefore, arthritic rats with lower serum IGF1 and liver Igf1 levels seem to be more sensitive to the stimulatory effect of EPA than control rats.

The positive effect of EPA on liver Igf1 gene expression can also be secondary to its effect on liver cells. In this sense, EPA is able to prevent LPS-induced increase in TNF expression in both liver cells alone or in liver cells cocultured with macrophages (Hao et al. 2010), and LPS directly inhibits Igf1 expression in hepatocyte cultures and in cocultures with Kuppfer cells (Priego et al. 2006, Granado et al. 2008). Furthermore, EPA induces cell proliferation in primary hepatocyte cultures (Liu et al. 2011), and IGF1 has been reported to be an important factor in proliferation and in the response to damage in liver cell (Gatto et al. 2008).

Several studies in humans have shown that long-term treatment with fish oil increases lean body mass whereas it decreases fat mass (Su \& Jones 1993, Noreen et al. 2010). The aforementioned authors reported that EPA decreases free cortisol levels, and that the decrease in cortisol can be the cause of a decrease in muscle proteolysis (Noreen et al. 2010). In our data, EPA administration was not able to prevent the stimulatory effect of arthritis on serum concentrations of corticosterone. The lack of effect of EPA on arthritis-induced corticosterone secretion can be due to the treatment length or to a difference in species.

Control rats treated with fenofibrate had decreased liver Igf1 and serum IGF1 and serum corticosterone levels were similar to those of arthritic rats. The stimulatory effect of fenofibrate

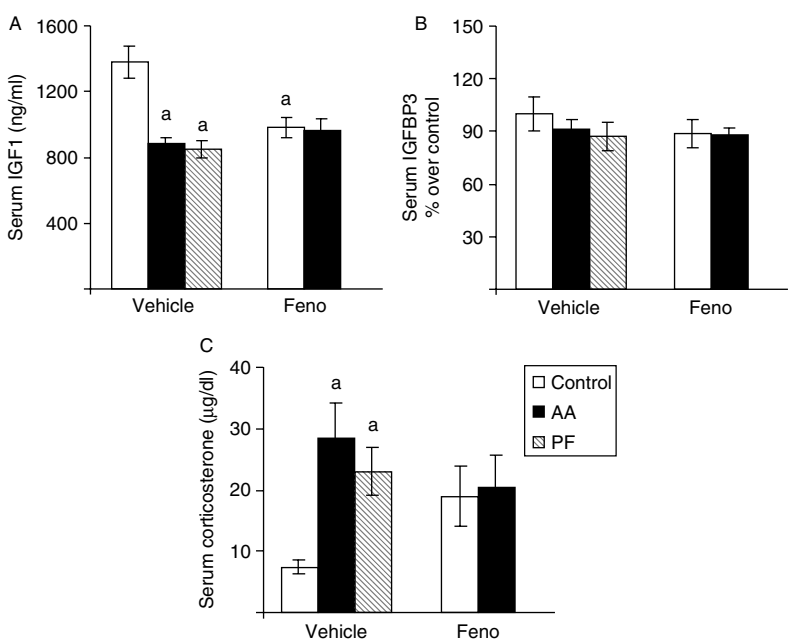

Figure 4 Serum concentrations of IGF1 (A), IGFBP3 (B), and corticosterone $(\mathrm{C})$ in control, arthritic (AA) or pair-fed (PF) rats treated with fenofibrate $(300 \mathrm{mg} / \mathrm{kg})$ or vehicle. Arthritis and fenofibrate decreased serum concentrations of IGF1 $(P<0 \cdot 01)$. Corticosterone levels were increased in arthritic rats $(P<0 \cdot 05)$. Pairfed rats had similar serum concentrations of IGF1 and corticosterone than arthritic rats. Data are expressed as mean \pm s.E.M. for $n=8-9$ rats per group, ${ }^{a}$ different from control rats treated with vehicle. 
on serum corticosterone has been previously reported (Chen et al. 2008). Taking into account the inhibitory effect of glucocorticoids on liver Igf1 and on serum IGF1 (Luo \& Murphy 1989), the increased corticosterone secretion can be one of the mechanisms through which fenofibrate inhibits IGF1 and Igf1 expression in control rats.

To our knowledge, there is no data about the effect of fenofibrate on liver Igf1 and serum IGF1, whereas data on Igf1 expression in organs other than the liver are contradictory. Activation of PPAR $\alpha$ by fenofibrate has an anti-cancer effect and attenuates signaling responses of IGF1R in medulloblastoma and glyoma cell lines (Urbanska et al. 2008, Drukala et al. 2010). In contrast, PPAR $\alpha$ activation in the heart, through Wy-14643 administration, results in upregulation of Igf1 expression in myocytes and subsequent protection against ischemia/reperfusion-induced apoptosis (El Azzouzi et al. 2011). A possible explanation is that either fenofibrate or Wy-14643 acts on the IGF1 system in a PPAR $\alpha$-independent manner.

Similarly to fenofibrate, thiazolidinediones such as rosiglitazone and pioglitazone are PPAR $\gamma$ ligands that have an antiproliferative effect and block IGF1 responses in cancer cells (Freudlsperger et al. 2006, He et al. 2006). Furthermore, rosiglitazone administration reduces serum IGF1 without modifying IGFBP3 levels in humans or mice, and also reduces Igf1 expression in liver cells, both in vivo and in vitro (Lecka-Czernik et al. 2007).

The inhibitory effect of fenofibrate on liver Igf1 and serum IGF1 observed in the present data contrasts with its protective action against muscle wasting that we found in arthritic rats (Castillero et al. 2011). A possible explanation can be the effects of fenofibrate on the Igfbps in the gastrocnemius. As previously reported (Castillero et al. 2009a), arthritis increased Igfbp 3 in the gastrocnemius, but not in the liver. These data suggest that Igf1 and Igfbp3 regulation in the skeletal muscle is different to its regulation in the liver. The increased expression of $I g f b p 3$ in the gastrocnemius of arthritic rats has been related to muscle atrophy. This hypothesis is based on the fact that IGFBP3 prevents IGF1 from binding to its receptor and it is able to inhibit cell proliferation by an
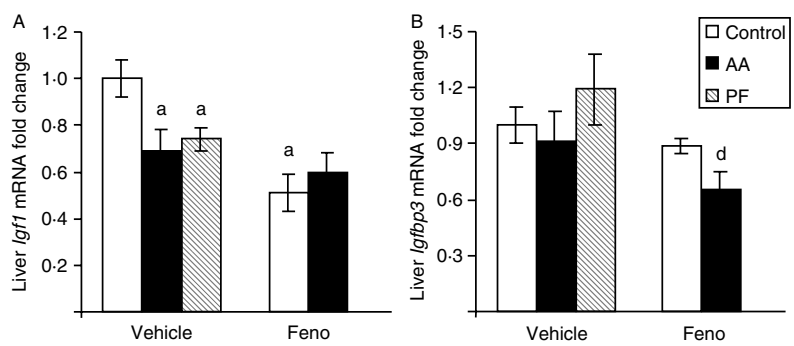

Figure 5 Effect of fenofibrate $(300 \mathrm{mg} / \mathrm{kg})$ administration on liver Igf1 (A) and lgfbp3 (B) mRNA in control, arthritic (AA) and pair-fed (PF) rats. Arthritis and fenofibrate decreased lgf1 mRNA $(P<0 \cdot 01)$. Data are expressed as mean \pm S.E.M. for $n=8-9$ rats per group, a different from control rats treated with coconut oil and different from pair-fed rats.

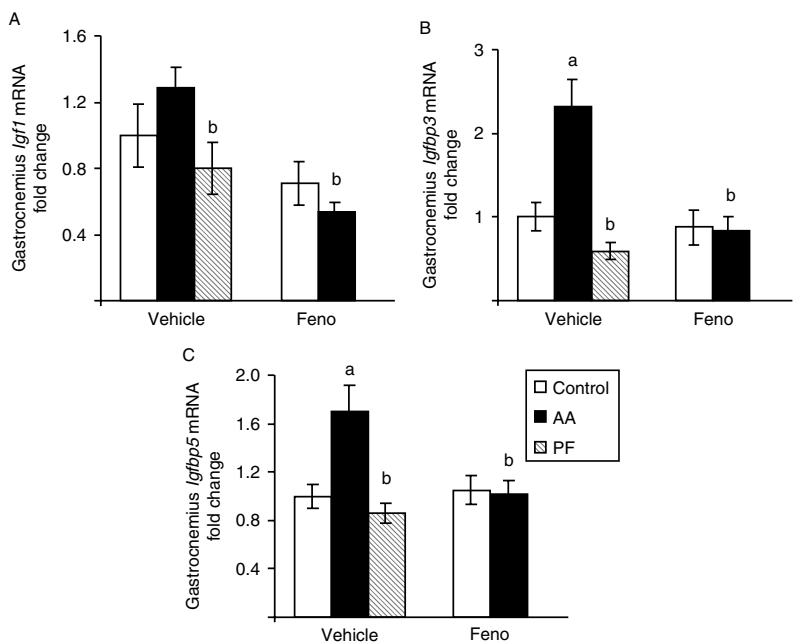

Figure 6 Effect of fenofibrate $(300 \mathrm{mg} / \mathrm{kg})$ administration on gastrocnemius Igf1 (A), Igfbp3 (B), and Igfbp5 (C) mRNA in control, arthritic (AA) and pair-fed (PF) rats. Arthritis increased Igfbp3 and Igfbp5 mRNA $P<0 \cdot 01$. In arthritic rats fenofibrate administration decreased Igf1, Igfbp 3 , and Igfbp $5 P<0 \cdot 01$. Pair-fed rats had lower Igf1, Igfbp3, and Igfbp5 mRNA than arthritic rats treated with vehicle. Data are expressed as mean \pm S.E.M. for $n=8-9$

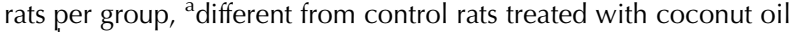
and ${ }^{b}$ different from arthritic rats treated with coconut oil.

IGF1-independent mechanism (Pampusch et al. 2003). IGFBP5 can also inhibit IGF1 action by preventing its binding to its receptors in the skeletal muscle (Mukherjee et al. 2008). Therefore, the inhibitory action of fenofibrate on Igfbp 3 and Igfbp 5 expression in the gastrocnemius muscle can explain the observed effect of fenofibrate attenuating muscle wasting in arthritic rats (Castillero et al. 2011).

In summary, our data indicate that EPA and fenofibrate have different effects on the IGF-IGFBPs in arthritic rats, which suggests that EPA actions on this pathway are not mediated by its PPAR $\alpha$ agonism. EPA administration prevented the inhibitory effect of serum IGF1 and on Igf1 gene in the liver, whereas fenofibrate administration prevented the stimulatory effect of arthritis on gastrocnemius Igfbp 3 and Igfbp 5 expression. The effects of both compounds on the IGF-IGFBPs system can explain their previously reported protective effects against muscle wasting, although these actions are exerted through different mechanisms.

\section{Declaration of interest}

The authors declare that there is no conflict of interest that could be perceived as prejudicing the impartiality of the research reported.

\section{Funding}

This work was supported by grants from FIS no PS09/00753 and Fundación Mutua Madrileña, fellowships from Gobierno Vasco to E C (BFI06.31) and from Ministerio de Educación y Ciencia to M L-M (BES-2007-16001). 


\section{Acknowledgements}

The authors are indebted to Dr Matti Tolonen for the supply of EPA, to Antonio Carmona for technical assistance and to Christina Bickart for the English correction of the manuscript.

\section{References}

Bonnet N \& Ferrari SL 2010 Effects of long-term supplementation with omega-3 fatty acids on longitudinal changes in bone mass and microstructure in mice. Journal of Nutritional Biochemistry 22 665-672. (doi:10. 1016/j.jnutbio.2010.05.006)

Castillero E, Martín AI, López-Menduiña M, Granado M, Villanúa MA \& López-Calderón A 2009a IGF-I system, atrogenes and myogenic regulatory factors in arthritis induced muscle wasting. Molecular and Cellular Endocrinology 309 8-16. (doi:10.1016/j.mce.2009.05.017)

Castillero E, Martín AI, López-Menduiña M, Villanúa MA \& LópezCalderón A $2009 b$ Eicosapentaenoic acid attenuates arthritis-induced muscle wasting acting on atrogin-1 and on myogenic regulatory factors. American Journal of Physiology. Regulatory, Integrative and Comparative Physiology 297 R1322-R1331. (doi:10.1152/ajpregu.00388.2009)

Castillero E, Nieto-Bona MP, Fernández-Galaz C, Martín AI, LópezMenduiña M, Granado M, Villanúa MA \& López-Calderón A 2011 Fenofibrate, a PPAR alpha agonist, decreases atrogenes and myostatin expression and improves arthritis-induced skeletal muscle atrophy. American Journal of Physiology. Endocrinology and Metabolism 300 E790-E799. (doi:10.1152/ajpendo.00590.2010)

Chen X, Li M, Sun W, Bi Y, Cai M, Liang H, Yu Q, He X \& Weng J 2008 Peroxisome proliferator-activated receptor alpha agonist-induced downregulation of hepatic glucocorticoid receptor expression in SD rats. Biochemical and Biophysical Research Communications 368 865-870. (doi:10. 1016/j.bbrc.2008.01.152)

Childs S, Hennessy AA, Sreenan JM, Wathes DC, Cheng Z, Stanton C, Diskin MG \& Kenny DA 2008 Effect of level of dietary n-3 polyunsaturated fatty acid supplementation on systemic and tissue fatty acid concentrations and on selected reproductive variables in cattle. Theriogenology 70 595-611. (doi:10.1016/j.theriogenology.2008.04.002)

Drukala J, Urbanska K, Wilk A, Grabacka M, Wybieralska E, Del Valle L, Madeja Z \& Reiss K 2010 ROS accumulation IGF-IR inhibition contribute to fenofibrate/PPARalpha-mediated inhibition of glioma cell motility in vitro. Molecular Cancer 9 159. (doi:10.1158/1541-7786.MCR10-0019)

El Azzouzi H, Leptidis S, Bourajjaj M, Armand AS, van der Nagel R, van Bilsen M, Da Costa Martins PA \& De Windt LJ 2011 Peroxisome proliferator-activated receptor (PPAR) gene profiling uncovers insulin-like growth factor-1 as a PPAR \{alpha\} target gene in cardioprotection. Journal of Biological Chemistry 286 14598-14607. (doi:10.1074/jbc.M111. 220525)

Evans WJ, Morley JE, Argilés J, Bales C, Baracos V, Guttridge D, Jatoi A, Kalantar-Zadeh K, Lochs H, Mantovani G et al. 2008 Cachexia: a new definition. Clinical Nutrition 27 793-799. (doi:10.1016/j.clnu.2008.06.013)

Forman BM, Chen J \& Evans RM 1997 Hypolipidemic drugs, polyunsaturated fatty acids, and eicosanoids are ligands for peroxisome proliferator-activated receptors alpha and delta. PNAS 94 4312-4317. (doi:10.1073/pnas.94.9.4312)

Freudlsperger C, Moll I, Schumacher U \& Thies A 2006 Anti-proliferative effect of peroxisome proliferator-activated receptor gamma agonists on human malignant melanoma cells in vitro. Anticancer Drugs 17 325-332. (doi:10.1097/00001813-200603000-00011)

Gatto M, Drudi-Metalli V, Torrice A, Alpini G, Cantafora A, Blotta I \& Alvaro D 2008 Insulin-like growth factor-1 isoforms in rat hepatocytes and cholangiocytes and their involvement in protection against cholestatic injury. Laboratory Investigation 88 986-994. (doi:10.1038/ labinvest.2008.63)

Granado M, Martín AI, López-Menduiña M, López-Calderón A \& Villanúa MA 2008 GH-releasing peptide-2 administration prevents liver inflammatory response in endotoxemia. American Journal of Physiology. Endocrinology and Metabolism 294 E131-E141. (doi:10.1152/ajpendo. 00308.2007)

Hao W, Wong OY, Liu X, Lee P, Chen Y \& Wong KK $2010 \omega$-3 fatty acids suppress inflammatory cytokine production by macrophages and hepatocytes. Journal of Pediatric Surgery 45 2412-2418. (doi:10.1016/j.jpedsurg. 2010.08.044)

He G, Sung YM, Digiovanni J \& Fischer SM 2006 Thiazolidinediones inhibit insulin-like growth factor-I-induced activation of p70S6 kinase and suppress insulin-like growth factor-I tumor-promoting activity. Cancer Research 66 1873-1878. (doi:10.1158/0008-5472.CAN-05-3111)

Hurst S, Rees SG, Randerson PF, Caterson B \& Harwood JL 2009 Contrasting effects of n-3 and n-6 fatty acids on cyclooxygenase- 2 in model systems for arthritis. Lipids 44 889-896. (doi:10.1007/s11745-0093347-x)

Ibañez De Cáceres I, Villanúa MA, Soto L, Martin AI \& López-Calderón A 2000 IGF-I and IGF-I-binding proteins in rats with adjuvant-induced arthritis given recombinant human growth hormone. Journal of Endocrinology 165 537-544. (doi:10.1677/joe.0.1650537)

James MJ \& Cleland LG 1997 Dietary n-3 fatty acids and therapy for rheumatoid arthritis. Seminars in Arthritis and Rheumatism 27 85-97. (doi:10.1016/S0049-0172(97)80009-1)

Lecka-Czernik B, Ackert-Bicknell C, Adamo ML, Marmolejos V, Churchill GA, Shockley KR, Reid IR, Grey A \& Rosen CJ 2007 Activation of peroxisome proliferator-activated receptor gamma (PPARgamma) by rosiglitazone suppresses components of the insulin-like growth factor regulatory system in vitro and in vivo. Endocrinology 148 903-911. (doi:10. 1210/en.2006-1121)

Leslie CA, Gonnerman WA, Ullman MD, Hayes KC, Franzblau C \& Cathcart ES 1985 Dietary fish oil modulates macrophage fatty acids and decreases arthritis susceptibility in mice. Journal of Experimental Medicine $\mathbf{1 6 2}$ 1336-1349. (doi:10.1084/jem.162.4.1336)

Liu WM, Shi FX, Lu LZ, Zhang C, Liu YL, Zhang J, Tao ZR, Shen JD, Li GQ, Wang DQ et al. 2011 Effects of linoleic acid and eicosapentaenoic acid on cell proliferation and lipid-metabolism gene expression in primary duck hepatocytes. Molecular and Cellular Biochemistry 352 19-24. (doi:10.1007/ s11010-011-0735-3)

López-Calderón A, Soto L \& Martín AI 1999 Chronic inflammation inhibits $\mathrm{GH}$ secretion and alters the serum insulin-like growth factor system in rats. Life Sciences 65 2049-2060. (doi:10.1016/S0024-3205(99)00472-5)

López-Menduiña M, Martín AI, Castillero E, Villanúa MA \& López-Calderón A 2010 Systemic IGF-I administration attenuates the inhibitory effect of chronic arthritis on gastrocnemius mass and decreases atrogin- 1 and IGFBP-3. American Journal of Physiology. Regulatory, Integrative and Comparative Physiology 299 R541-R551. (doi:10.1152/ajpregu.00211.2010)

Luo J \& Murphy LJ 1989 Dexamethasone inhibits growth hormone induction of insulin-like growth factor-I (IGF-I) messenger ribonucleic acid (mRNA) in hypophysectomized rats and reduces IGF-I abundance in the intact rat. Endocrinology 125 165-171. (doi:10.1210/endo-125-1-165)

Machado RV, Mauricio AF, Taniguti AP, Ferretti R, Neto HS \& Marques MJ 2011 Eicosapentaenoic acid decreases TNF- $\alpha$ and protects dystrophic muscles of mdx mice from degeneration. Journal of Neuroimmunology 232 145-150. (doi:10.1016/j.jneuroim.2010.10.032)

Michalik L \& Wahli W 2008 PPARs mediate lipid signaling in inflammation and cancer. PPAR Research 2008 Article ID 134059. (doi:10.1155/2008/134059)

Morley JE, Thomas DR \& Wilson MM 2006 Cachexia: pathophysiology and clinical relevance. American Journal of Clinical Nutrition 83 735-743.

Mukherjee A, Wilson EM \& Rotwein P 2008 Insulin-like growth factor (IGF) binding protein- 5 blocks skeletal muscle differentiation by inhibiting IGF actions. Molecular Endocrinology 22 206-215. (doi:10.1210/me.2007-0336)

Noreen EE, Sass MJ, Crowe ML, Pabon VA, Brandauer J \& Averill LK 2010 Effects of supplemental fish oil on resting metabolic rate, body composition, and salivary cortisol in healthy adults. Journal of the International Society of Sports Nutrition 7 31. (doi:10.1186/1550-2783-7-31)

Okamoto H, Iwamoto T, Kotake S, Momohara S, Yamanaka H \& Kamatani N 2005 Inhibition of NF-kappaB signaling by fenofibrate, a peroxisome proliferator-activated receptor-alpha ligand, presents a therapeutic strategy for rheumatoid arthritis. Clinical and Experimental Rheumatology 23 323-330. 
Pampusch MS, Kamanga-Sollo E, White ME, Hathaway MR \& Dayton WR 2003 Effect of recombinant porcine IGF-binding protein-3 on proliferation of embryonic porcine myogenic cell cultures in the presence and absence of IGF-I. Journal of Endocrinology 176 227-235. (doi:10.1677/joe.0. 1760227)

Pawer A \& Jump DB 2003 Unsaturated fatty acid regulation of peroxisome proliferator-activated receptor a activity in rat primary hepatocytes. Journal of Biological Chemistry 278 35931-35939. (doi:10.1074/jbc. M306238200)

Priego T, Granado M, Castillero E, Martín AI, Villanúa MA \& LópezCalderón A 2006 Nitric oxide production by hepatocytes contributes to the inhibitory effect of endotoxin on insulin-like growth factor I gene expression. Journal of Endocrinology 190 847-856. (doi:10.1677/joe.1. 06938)

Simopoulos AP 2002 Omega-3 fatty acids in inflammation and autoimmune diseases. Journal of the American College of Nutrition 21 495-505.

Soto L, Martín AI, Millán S, Vara E \& López-Calderón A 1998 Effects of endotoxin lipopolysaccharide administration on the somatotropic axis. Journal of Endocrinology 159 239-246. (doi:10.1677/joe.0.1590239)

Su W \& Jones PJ 1993 Dietary fatty acid composition influences energy accretion in rats. Journal of Nutrition 123 2109-2114.

Tanaka H, Ueta Y, Yamashita U, Kannan H \& Yamashita H 1996 Biphasic changes in behavioral, endocrine, and sympathetic systems in adjuvant arthritis in Lewis rats. Brain Research Bulletin 39 33-37. (doi:10.1016/03619230(95)02037-3)
Tashiro T, Yamamori H, Takagi K, Hayashi N, Furukawa K \& Nakajima N 1998 n-3 versus n-6 polyunsaturated fatty acids in critical illness. Nutrition 14 551-553. (doi:10.1016/S0899-9007(98)00048-3)

Touati G, Prieur AM, Ruiz JC, Noel M \& Czernichow P 1998 Beneficial effects of one-year growth hormone administration to children with juvenile chronic arthritis on chronic steroid therapy. I. Effects on growth velocity and body composition. Journal of Clinical Endocrinology and Metabolism 83 403-409. (doi:10.1210/jc.83.2.403)

Urbanska K, Pannizzo P, Grabacka M, Croul S, Del Valle L, Khalili K \& Reiss K 2008 Activation of PPARalpha inhibits IGF-I-mediated growth and survival responses in medulloblastoma cell lines. International Journal of Cancer 123 1015-1024. (doi:10.1002/ijc.23588)

Volker DH, FitzGerald PE \& Garg ML 2000 The eicosapentaenoic to docosahexaenoic acid ratio of diets affects the pathogenesis of arthritis in Lew/SSN rats. Journal of Nutrition 130 559-565.

Zhao Y, Joshi-Barve S, Barve S \& Chen LH 2004 Eicosapentaenoic acid prevents LPS-induced TNF-alpha expression by preventing NF-kappaB activation. Journal of the American College of Nutrition 23 71-78.

Received in final form 13 June 2011

Accepted 29 June 2011

Made available online as an Accepted Preprint 29 June 2011 